\title{
The Sublimeness of Sleaze in the NNPC in the Fourth Republic, 1999 - 2007: A Historical Conspectus
}

\author{
Dr. M. S. Audu ${ }^{1}$, Osuala, Uzoma S. ${ }^{2}$ \\ 1, 2,Department of History, Federal University, Lokoja, Kogi State, Nigeria
}

\begin{abstract}
The discovery of crude oil in Nigeria in 1956 ushered in hope for economic prosperity and rapid developmental opportunities for the nation. Hence, in subsequent years, the Federal Government established the Nigerian National Oil Company (NNOC), a regulatory body to monitor and regulate oil production activities. However, the inefficiency and lapses in NNOC resulted in the emergence of the Nigerian National Petroleum Corporation (NNPC) in 1977. Nonetheless, the new agency had been a subject of criticism consequent upon its inadequacy to manage, monitor and control oil production and accountability within and outside the country. The inefficiency over the years assumed an unprecedented progression which metamorphosed into sublime of sleaze in the Fourth Republic. It is in the light of this malfeasance that the discourse examines in historical perspective the decadence of decorum in NNPC in the Fourth Republic. The methodology is thematic, chronological and analytical making use of primary and secondary sources. The scholarly essay posited that NNPC under the ex-president, Olusegun Obasanjo's eight years in office witnessed the most scandalous sleaze the oil sector had ever experienced. The paper offered some caveats for NNPC operations in subsequent years if Nigeria must reap the reward - in all ramifications - of the oil discovery in 1956.

Keywords: Sublimeness, Sleaze, NNPC, Fourth Republic
\end{abstract}

\section{INTRODUCTION}

The relevance of the oil discovered in Oloibiri in 1956 by the leading oil company - Shell D'Acry (later Shell-BP Petroleum Development Company of Nigeria) ${ }^{1}$ offered Nigeria a prosperously economic future and a rapid developmental strides among the comity of nations. The discovery became more relevant at a period when an end to the country's colonial epoch was much talked about. In about a year after the discovery of petroleum products, the Eastern and the Western Regions opted for nominal independence. The Northern Region had hoped to achieve same in $1959 .^{2}$ Thus, by October 1, 1960, Nigeria became a sovereign nation and blessed with unimaginable quantity of oil wells across the Niger-Delta region, the country was labelled 'the Giant of Africa'. The appellation was attributable to the immense population of the country buoyed by the oil deposits surrounding her territorial waters. Years later, international oil companies (IOCs) constituted major oil operators in Nigeria. In order to oversee, monitor and regulate the operations of the IOCs, the Federal Government established the Nigerian National Oil Company (NNOC) in $1971 .^{3}$ However, the inefficiency and inadequacy of the NNOC to properly coordinate the oil sector inhibited by the double-dealings of the IOCs compelled the government to enforce stricter control of the petroleum sector led to the emergence of the Nigerian National Petroleum Corporation (NNPC) in 1977. Hence, the central role of NNPC in the Nigerian political-economy was unquestionable and apparent. This shall be returned to anon.

Several years on, the military ruled the country and invariably managed the oil sector. However, this changed in 1999, when the nation returned to democratic governance ushering in the Fourth Republic. Under the $4^{\text {th }}$ Republic and for the first time in the annals of the nation's history, the presidency directly supervised and presided over the petroleum sector. ${ }^{4}$ The president had been said to have taken this decision on the consideration of inefficiency and maladministration in the oil sector over the years. ${ }^{5}$ Nonetheless, with the president presiding as the 'Petroleum Minister', the sector had witnessed the worst and unprecedented corrupt practices in history. For instance, in 2008, Hamman Tukur, Chairman Revenue Mobilisation, Allocation and Fiscal Commission (RMAFC) reported to the Yar' Adual administration that Nigeria lost about $\$ 555$ billion (naira) between December 2004 and April 2007 (the second part of the $4^{\text {th }}$ Republic) under president Olusegun Obasanjo that would have accrued to the Federation Account due to lack of transparency and accountability in computation and procedure of payment for fuel subsidy. ${ }^{6}$

The nation in the Fourth Republic witnessed the highest production of barrels of oil per day since independence ${ }^{7}$, however, the oil wealth and the revenue derived from the industry in the eight years never manifested to improve infrastructural development, wealth generation, poverty reduction and appreciation in living standard for majority of Nigerians. The petroleum sector under the auspices of NNPC and supervised by the presidency was wrought with unparalleled sublimeness of sleaze in the history of the country. It is in the 
light of the above that the paper examines the spate of the NNPC operations in the Fourth Republic in relation to corruption. The essay is segmented into four thematic stages with sub-headings therein.

\section{THE Evolution OF THE NNPC: A HistoriCAL APPROACH}

The NNPC came into existence twenty-one years after oil was discovered in Nigeria under the military regime of Murtala/Obasanjo administration, 1975-'79. Olusegun Obasanjo had by accident become the head of state following the assassination of General Murtala Muhammed in 1976. This was at a time when Nigeria was to benefit immeasurably from the boom in oil surfeit in the 1970s. Therefore, the oil sector was considered to be the goose that would underlay Nigeria future economic and technological advancement. Thus, precautions and prerogative measures were taken by the regime of Obasanajo to cushion against any maladministration and mismanagement in the sector. Consequently, the emergence of NNPC, a body saddled with the responsibility of ensuring the production, marketing and regulating the petroleum industry as well as driving the Nigeria's economic, industrial and technological development primarily through the achievement of endogenous capacities and self-reliance in all spheres of upstream and downstream operations. ${ }^{8}$

However, prior to the emergence of NNPC in April 1977, it necessary to examine the developments of the Nigerian infant oil sector before the emergence of NNOC, the precursor to NNPC. There was dearth of considerable literature of the first fifteen years of oil exploration in the country since its (oil) discovery in 1956. Hence, the documents available are lacking details. This is attributable to the fact that within those periods, Nigeria's oil exploration was dominated and controlled by the IOCs. In addition, the devastating Nigerian civil war equally destroyed the scanty literature on the operations of those companies. Therefore, suffice it to say that Nigeria oil sector since its discovery was dominated by international oil companies (IOCs). It is to the activities of these companies that we shall draw attention to.

Oil discovery in Nigeria by Shell-BP attracted other IOCs across the West into Nigeria. This is needless to say gave the IOCs an opportune privilege to explore the country crude oil. At this point, the IOCs provided the technical know-how and expertise as well as capital needed for operations. Therefore, from the onset, the IOCs inherently and invariably had control and leverage in the exploration and refining of the nation's crude oil. Impressed by the activities of the IOCs, the Federal government encouraged the international oil companies to finance the building and operation of refineries in the country. Hence, Shell, the crown prince of the IOCs in Nigeria built one refinery in Port Harcourt in $1965 .{ }^{9}$ Encouraged by the prospects of the oil sector and the operations of the IOCs, the Federal government provided enabling environments in regard to fair tax assessment cum provision of security, electricity, transportation, port and communication facilities and other essential amenities. With regard to the above and in comparison to other resource owning countries, Nigerian arrangements with IOCs were relatively favourable because extant 'covenants' between the Federation and the IOCs guaranteed the latter equal to the most favourable terms accorded to any other. ${ }^{10}$

In 1969, the Federal government introduced the Petroleum Act which contained two important clauses of discontinuities in participatory rights in the oil sector. First, it provided that only Nigerian citizens or companies incorporated in Nigeria may be granted exploration, prospecting and mining licences. Second, it reserved to the Federation a discretionary option of part ownership in all new concession. ${ }^{11}$ The motives for such decisions perhaps had been attributed to the lapses and un-regulatory activities of the IOCs. For instance, in spite of the economic rent from the IOCs, the production depended on the calculations of over-seas based corporate headquarters. This implied that the industry had limited impact on the economy in terms of domestic factor input, reinvestment and other linkages. ${ }^{12}$ Furthermore, it was likely that anticipated increased dependence of the Federation on payments by IOCs would give the latter an opportunity for greater political leverage in future. ${ }^{13}$ For example, Shell showed an early sign of IOC muscle when it supplied gasoline to secessionist Biafra during the civil war, despite Nigerian government's disapproval. ${ }^{14}$ It was equally suspected that the royalty and sales tax payments the IOCs made to the government were based on 'posted' prices below realized market value. ${ }^{15}$

Thus, given the undefined relations on petroleum exploration and other nature of the IOCs operations, the Federal government therefore, strengthened its oversight functions to direct participation in the sector with the Federation's first acquiring equity interest in the industry in $1971 .{ }^{16}$ The decision was compelling and necessary with Nigeria's entry into OPEC that year (July 1971); OPEC had required member states to nationalize the oil industry. More far-reaching than that was Nigeria sweeping nationalization programme in 1972 , requiring all investing in the economy to have a minimum of $60 \%$ Nigerian equity participation. Thus, the government began to acquire participatory interest in the operations of and assets in the IOCs. Consequently, that same year, NNOC and NNPC's precursor was established to manage the Federation's majority stake in the oil industry, to exploration, facilities construction and marketing of the Federation's programmed equity code. Nonetheless, and still handicapped with the requisite technology and capital needed in the operations of the petroleum industry, NNOC entered into mostly Joint Venture (JV) agreement with the operating IOCs. ${ }^{17}$ 
The six years' (1971-1977) existence of NNOC was shrouded with unmitigated and dysfunctional operational complexities. In the first place, the agency was at loggerheads with DPR over regulatory functions. DPR was created in 1970 to enhance Nigeria's regulatory functions, but NNOC competed for these functions after its formation one year later. ${ }^{18}$ In another instance, in the mid 1970s, professionals in NNOC set prices for Nigerian crude using OPEC formula, but these prices were routinely revised downwards by senior civil servant in the Ministry of Mines and Power. The same ministry officials did not allow NNOC professionals 'to develop oil related activities within the corporation which was becoming a shell without function. ${ }^{19}$ Thus in 1975/76, the Nigeria oil industry was described as a 'wasting asset'. ${ }^{20}$ Amidst the operational complexities, the NNOC was suspicious of corruption as reported by the probe panel that investigated the corporation's activities. The panel discovered that highly-placed NNOC had instigated preferential discount to select buyers of Nigerian crude and engineered other trading practices that benefitted selected IOCs and trades. ${ }^{21}$ As a result, the covert operational sleaze, nepotism and favouritism denied the country from taking advantages of price increases spawned by 1973-'74 shortages. The panel established serious transparency breaches on the part of NNOC senior management among other anomalies. Thus, based on the revelations and recommendations of the panel, the military administration of Olusegun Obasanjo dissolved the NNOC in 1977 and replaced it with NNPC. Thus, the birth of NNPC in April 1977 by Decree 33. ${ }^{22}$ To avoid unnecessary struggle for regulatory functions experienced among the previous agencies, the newly formed NNPC assumed the powers and responsibilities of NNOC, the DPR and the Ministry of Petroleum Resources and Energy.

If NNPC was formed among other operational anomalies and in the hope of ending corruption in the NNOC, such optimism was clearly misplaced. Corruption became more overt, extensive and widespread in NNPC since its inception. Diversion of crude oils and project, funds, underreporting of crude oil output, inflation of contracts and importation of substandard fuel have been some of the conduits of corruption in the corporation. ${ }^{23}$ If NNPC had known corruption over the years with particular reference to the eighteen years of military regime since 1977, the NNPC witnessed and experienced unabashed and brazen sleaze in the Fourth Republic, 1999-2007. It is to these developments that the rest of the paper shall focus on.

\section{THE NNPC IN THE FOURTH REPUBLIC, 1999-2007: THE SUBLIMENESS OF SLEAZE}

On May 29, 1999, the 'Khaki Boys' retreated back to the barracks under the command of General Abdusalam Abubakar, thus ushering in the commencement of the Fourth Republic. At the helm of affairs in the newly democratic dispensation was Chief Olusegun Obasanjo, the former military head of States, 1976-1979. For his antecedent in 1976 - 1979, Nigerians greeted the election of Obasanjo with enthusiasm and hope for better democratic governance. The nation had overwhelmingly expected Olusegun Obasanjo's regime in the Fourth Republic to break even in all levels of governmental parastatals especially with the petroleum sector under the auspices of NNPC. The oil industry in the last four decades had determined the political-economy as well as industrial growth and development of the nation. In 1999 for instances, the oil sector constituted over 98\% (per cent) of Nigerian foreign exchange and source of revenue. ${ }^{24}$ However, the industry had been synonymous with corruption. It would be recalled that the NNPC was created by the military regime of Olusegun Obasanjo in 1977 primarily to get rid of the inefficiency and sleaze in NNOC, the forerunner to NNPC.

The years that preceded the Fourth Republic in NNPC were characterised with corruption. Hence, the president, Obasanjo in his 1999 cabinet held unto the Ministry of Petroleum Resources and Chair of NNPC board. ${ }^{25}$ In other words, the president for the first time became the de facto Minister of Petroleum and Chairman of NNPC board. According to the presidency, the decision was undertaken in order to sanitize the oil industry that was enveloped in wanton sleaze. However, the Fourth Republic was a contradiction of the acclaimed reformed policies in NNPC led by Obasanjo. It is said that the regime perpetrated crude oil fraud via NNPC through the following major conduits; ${ }^{26}$

$\checkmark$ Incessant hike in the price of petroleum products

$\checkmark$ Deliberate and unaccounted increase in the daily quota of petroleum production against OPEC allocation

$\checkmark \quad$ Misappropriated fund budgeted for the Turn-Around Maintenance

$\checkmark$ Fraudulent allocation of oil blocks

$\checkmark \quad$ Lack of transparency and imprudence in NNPC bills

$\checkmark$ Through crude oil theft known as 'Smuggling' across Nigeria porous borders

$\checkmark$ Deliberate delay in discharging of petroleum products by ships at the seaports

$\checkmark$ The Dubious Operations of International Oil Companies (IOCs)

It is to these developments in NNPC in the Fourth Republic that we shall turn to. 


\subsection{Incessant hike in the price of petroleum products}

Adjudging the sleaze in the Fourth Republic's administration, we begin with the manifestation of incessant hike in the price of petroleum six months after Obasanjo assumption into Aso Rock (Nigeria Seat Power House). In 1999 when the Obasanjo government came to power, fuel price was 11 per litre. Six months after the inauguration of the government, the price of fuel was raised to $\$ 20$. Not satisfied with the new price, Obasanjo, again in June 2000 hiked the price from $\$ 20$ to $\$ 30$, but the Nigerian Labour Congress (NLC) forced the government to keep the price at $\$ 22$. Shortly after this, Obasanjo administration raised the fuel price from $\$ 22$ to $\$ 26$, then to $\$ 40$ and later $\$ 65$. And few days to leave office, Obasanjo increased the price of fuel to $\$ 75$ as a parting gift to Nigerians. ${ }^{27}$ Obasanjo had argued that the increase in the petroleum price products was in line with the deregulation in the downstream sector. He averred that the proceeds from the deregulation was intended for the development of other sectors like education, health and provision of infrastructure facilities for Nigerians. ${ }^{28}$ However, in an interview, Gani Fawehinmi argued that Obasanjo had squandered the proceeds from the hike in the price of petrol as well as to perpetuate corruption. He stressed that Obasanjo went on a COJA jamboree when the educational sector was in a state of comatose and the health sector in a collapsed state. ${ }^{29}$ Among the spendthrift of Obasanjo was the $\$ 30$ billion (about $\$ 250,000$ ) sunk into the $20038^{\text {th }}$ All African Games, over $\$ 10$ billion (over \$82,000) spent on hosting the Commonwealth Heads of Government Meeting (CHOGM). Obasanjo also spent 10 billion to increase the number of jets in the Presidential fleets and $\$ 73$ billion (over $\$ 600,000$ ) in the construction of National Stadium in Abuja. ${ }^{30}$ For example, in January $2002{ }^{31}$ the Academic Staff Union of Universities (ASUU) embarked on a six months nationwide strike as a result of the dilapidating state of the Nigerian universities. Obasanjo severally and incessantly increased the price of fuel within eight years of his regime rising from $\$ 20$ in 1999 to $\$ 75$ at the expiration of the regime in 2007. In spite of the revenue from the hike in the price of fuel, he failed to improve the standard of education, restore the health sector and rehabilitate the dilapidating infrastructures. The administration equally failed to sanitize NNPC that was characterized with mismanagement and massive unaccountability despite the over-blown economic reform proclaimed by the regime.

\subsection{Deliberate and unaccounted increase in the daily quota of petroleum production against OPEC allocation}

The deliberate and unaccounted increase in the daily quota of petroleum production as against figures allocated to Nigeria by OPEC in the Fourth Republic was another means through which corruption was executed in NNPC. Between June and December 1999, OPEC gave Nigeria a quota of 403,390,000 barrels and NNPC rather produced $449,774,745$, an excess of $46,384,745$ barrels. In 2000 , the excess was taken up to $80,607,101$ when NNPC produced a total crude quantity of 828,618,101 instead of 748,011,000 approved by OPEC. In 2001, there was an excess production of $135,201,184$ from a total of $863,835,184$ as against OPEC quota of 728,634,000. OPEC, in 2002 gave NNPC crude oil quota of $478,851,000$. In lieu of sticking to this quota, NNPC produced 542,103,211, which was an excess of 63,252,211. ${ }^{32}$ Thus, between 1999 and 2002, all the excesses of NNPC crude oil productions added up was $325,445,241$. Based on the oil price of $\$ 25$ per barrel at the prevailing exchange rate of $\$ 111.6$ to $\$ 1$ at the period, Nigeria lost $\$ 913,572,222,390$ billion (over $\$ 800$ million to the scam). During the second phase of the Fourth Republic $(2004$ - 2007) under the Obasanjo-led NNPC, it was reported that Nigeria via NNPC lost about $\$ 555$ billion (over $\$ 500$ million) that would have accrued to the Federation account to lack of transparency and accountability in computation and procedure of payment for fuel subsidy. ${ }^{33}$ Such whopping amount was embezzled and unaccounted for in a nation whose citizen lived in abject poverty, dilapidated infrastructures and whose citizen standard of living, education and health programmes were in comatose. Definitely, it portrays contradiction in the administration that championed anti-graft policies. It obviously indicates the decadence of decorum in NNPC and sublimeness of sleaze under the petroleum minister - Olusegun Obasanjo.

\subsection{Misappropriated fund budgeted for the Turn-Around Maintenance}

The Turn-Around Maintenance (TAM) was another conduit in the perfection of corruption in NNPC in the Fourth Republic. The issue of refineries and TAM had remained a major sore point in the management of the downstream sector of the oil industry in Nigeria. Successive governments have virtually turned the TAM into a cash cow for close associates and a massive drain pipes to the detriment of the larger Nigerian populace. The purpose of TAM is usually to reduce the number of shutdowns due to failure of equipment or power and to increase efficiency and improve performance..$^{34}$ There are four levels of TAM known worldwide: the preventive, the maintenance, the shutdown and the investment. By 1999 when the Fourth Republic began, the major refineries (Port Harcourt, Warri, Kaduna and Lagos) had operated below potential capacity. For example, Obasanjo inherited refineries that were largely unserviceable, operating below 450,000 barrels per day. ${ }^{35}$ The former president promised to reverse the trend. However, the capacity fell from 250,000 barrels per day as at May21, 1999 to about 150,000 barrels per day in 2001. ${ }^{36}$ Between 1999 and 2003, Obasanjo's regime had spent 
over $\$ 1$ billion on TAM without any significant improvement. ${ }^{37}$ This had been attributed to corrupt practices during his administration. The reason for this had been given by Peter Esele, President of Petroleum and Natural Gas Senior Association of Nigeria (PENGASSAN). He maintained that contracts for the TAM were usually given to quacks who had no knowledge about oil refinery. ${ }^{38}$ This was the situation and waste in TAM. Hence, Nigeria still import refined oil products as a result of corruption that enveloped Obasanjo and NNPC era. Gani Fawehinmi, remarked that none of the refineries is working because contractors for TAM were given to corrupt political cohorts on corrupt terms and at the end nothing came out of them. ${ }^{39}$

\subsection{Fraudulent allocation of oil blocks}

The fraudulent allocation of oil blocks in the Obasanjo-led NNPC exhibited the height and sublimeness of sleaze in the Fourth Republic. In the allocation of oil blocks, Umar, former military governor of Kaduna State explained that allocation was preceded by the usual Obasanjo deceptive manoeuvres intended to give the process some semblance of credibility. He emphasized that $70 \%$ (per cent) of oil blocks allocated by the Obasanjo's administration were cornered by him, his families and business cronies through dubious process. ${ }^{40}$ Instances of allocation of oil blocks abound: through Tony Anenih, former Minister of Works known as 'Mr. Fix', the former president, Obasanjo awarded oil blocks to A \& Hatman Limited controlled by the Edo-born politician. He also awarded oil locks to ERHC, a United States company, controlled by Chrome Energy owned by Emeka Offor, who was then an ally of the former president. ${ }^{41}$ Through these measures, billions of USD were siphoned out of the country and the refineries remained redundant.

\subsection{Lack of transparency and imprudence in NNPC bills}

Another instance of lack of transparency in the Obasanjo-led NNPC was the imprudent bills and improper accountability of NNPC officials with reference to Jackson Gaius-Obaseki, the former GMD OF NNPC. Between the first four years of Obasanjo tenure, NNPC spent a whopping sum of $\$ 240$ million (over \$1.9 million) on Obaseki's hotel bill at the NICON Hilton Hotel, Abuja. ${ }^{42}$ Again, in July 2008, the former GMD of NNPC and the former director of the Pipeline and Product Marketing Company (PPMC), Gaius-Obaseki and Dan Nzelu respectively bought fuel oil from the PPMC at a subsidized domestic price of 8 8.30k per litre (\$60.00 per tonne) and exported same at $\$ 165.00$ per tonne. Due to this illegitimate transaction, the nation through the NNPC lost over $\$ 160$ million. The PPMC should have made a gross income of more than $\$ 250$ million, however, it made an income of $\$ 90$ million due to ambiguity in the transaction. ${ }^{43}$ At the end of the saga, Obaseki and Nzelu were exonerated of the lapses. This is just part of lack of transparency and unaccountability that bedevilled Obasanjo-led NNPC administration. The shady operations in the NNPC were exposed in 2008 by the Hart Group, a British Audit Firm. The firm reported that between 2001 and 2004, the nation lost about 22 million barrels of crude oil production. ${ }^{44}$ The situation was among the sharp practices of corruption and scam in the NNPC during the Fourth Republic. In the award of oil blocks and other contracts, Demola Abimbaye ${ }^{45}$ had reported that Obasanjo awarded juicy contracts to his daughter in-law who had no knowledge in the oil sector. The situation showed lack of transparency in NNPC between 1999 and 2007

\subsection{Through Crude Oil Theft known as 'Smuggling' across Nigeria porous borders}

The NNPC had also suffered another scam through the smuggling of Nigeria's oil to the neighbouring countries like Cameroon, Republic of Benin and Ivory Coast. For example, in 2003, through the activities of smugglers, more than 30 million litres of fuel worth more than 1.056 billion had been smuggled out of the country into Cameroon and other African ountries. ${ }^{46}$ The situation had contributed to scarcity of fuel in the country with its attendant problems. It is reliably gathered that the activities of fuel smuggling was usually carried out by unscrupulous marketers mainly from Taraba, Adamawa and Benue States. Among the thriving route was the Birnin Konni, Maradi-Gaya, Kondi Sokoto, North-west axis into Republic of Niger. Other routes run from Niger State through Kaduna and Kano via Jigawa, all in Central-north Nigeria into Republic of Niger. The South-west route ran from Otta through Owode, Ilase (in Ogun State), Ajegunle and Idiroko (in Lagos State) to Republic of Benin. In the South-south, Abuloma Jelty, Ogoni and Ikwerre were notorious routes. ${ }^{47}$ Through these routes, millions of barrels and billions of dollars had been lost to smugglers without any commendable efforts by the Obasanjo administration to curb it.

\subsection{Deliberate delay in discharging of petroleum products by ships at the seaports}

Another sleaze in NNPC was the deliberate delay in discharging of petroleum products by ships at the seaports. Through this measure, the nation via the NNPC lost over $\$ 12$ million daily as demurrage. Demurrage is the penalty paid based on number of days spent above the limit allowed for clearance or off-loading of goods. During the Obasanjo-led Fourth Republic, NNPC paid $\$ 10,000$ per vessel on about ten (10) vessels as demurrage per day. At the exchange rate of $\mathrm{N} 121.88$ to a dollar at the time, the demurrage per day on just one vessel was $1,218,000{ }^{48}$ Payment of demurrage takes effect three days after the arrival of the vessel. The 
financial implications of the demurrage burden to the NNPC and the nation was enormous as official documents stated that some of the vessels bringing in petroleum vessels spent up to three months before they were discharged of their contents. For instance, by September 13, 2007, MT Minerva Xanthe had spent 94 days in Nigeria, MT Ioannis $P$, also spent 94 days and MT N S Silver spent 88 days. The duration of days spent by $M T$ Overseas Allenmar was 83 days, while MTZygi and MT Freja Atlantic had waited for 92 and 93 days respectively. ${ }^{49}$ To sum it up, NNPC paid over $\$ 12$ million (circa $\$ 100,000$ ) for the ten (10) vessels per day and paid over 1 billion (about $\$ 9000000$ ) for these vessels for three months to the NNPC official cabals who reaped from the deliberate delay in discharging the vessels and the petroleum contents. At other times, the number of days spent were often inflated and the differences shared between members of the cabals and vessel operators. ${ }^{50}$ This was among the unwholesome sleaze in the NNPC in the Fourth Republic.

\subsection{The Dubious Operations of International Oil Companies (IOCs)}

Obasanjo-led NNPC equally engaged in oil sleaze that cut across the shores and borders of the country. In his oil deal with Jamaican Oil Companies (Petroleum Corporation of Jamaica), Obasanjo had been accused of lack of transparency and accountability. It all began in 1978 when Obasanjo was the military Head of States. In an agreement Obasanjo reached with the Jamaican leaders, Jamaica was allowed to lift oil from Nigeria from May $1,1979 .{ }^{51}$ The situation continued until the relationship went sour during the administration of General Buhari in 1984. First, Nigeria ordered that all countries trading in Nigeria oil must post a $\$ 1$ million band and that they were to make huge investments in the Nigerian economy, ${ }^{52}$ a task which PCJ was not equal to. The situation lasted until 1999 when Obasanjo became the President in the Fourth Republic. However, when Obasanjo came to power, he exhumed PCJ's file without due process. Without following the routine of Code of Conduct Bureau, Obasanjo approved another trade agreement with Jamaica. Thus, on October 2000, Jamaica commenced oil lifting in Nigeria. Between October 2000 and April 2006, Jamaica lifted a total oil volume of 37.2 million barrels unaccounted which gave PCJ an income of $\$ 2.8$ million ${ }^{53}$ without tax assessment of any sort. On this, Obasanjo-led NNPC and administration contradicted with his due process campaign and acclaimed reformed economy cum NNPC.

The last scandal that rocks the Obasanjo-led NNPC in the Fourth Republic before leaving office was the $\$ 6$ million Wilbros bribery scandal. Wilbros Group Incorporated (WGI) is a Texas, U.S. based oil service with subsidiaries in Nigeria and some other countries. ${ }^{54}$ In a desperate bid to win the multi-million dollars Eastern Gas Gathering System (EGGS) contract from the NNPC, its officials led by Steph Jason Edward raised money to bribe some prominent Nigerians in NNPC and the ruling party, Peoples Democratic Party during the regime of former president, Olusegun Obasanjo. The Wilbros had won the first phase of the EGGS contract which involved engineering, procurement and construction of a pipeline from the Soku Gas Plant to the Bonny Island and Liquefied Natural Gas Plant. The first phase bid was to cost $\$ 246,500,000$ while the EGGS phase two was to cost $\$ 141,000,000$. A total of $\$ 387,500,000 .{ }^{55}$ It was in a desperate bid to get the second phase that Steph offered the $\$ 6$ million bribe that was shared among top officials under Obasanjo. The bribery scandal exhibited the rot in NNPC and the Fourth Republic.

\section{SOME CAVEATS AND CONCLUSION}

In this paper, we have been able to trace the historical emergence of NNPC. It is established that the sleaze in NNOC and lack of direction led to the establishment of NNPC in 1977 by General Obasanjo. However, the sleaze in NNPC since its inception took an unprecedented and geometric turn in the Fourth Republic under the President Olusegun Obasanjo. In all facets of the NNPC operations: from the daily quota of petroleum production, the turn-around maintenance, the allocation of oil blocks and contracts, extravagant and ostentatious lifestyle of NNPC officials, the smuggling of oil out of the country and to the deliberate delay of refined products by ships at the seaports is bedevilled with disgusting and unabashed corruption. In spite of the billions of dollars that was generated from the oil industry in Nigeria, the condition and standard of living in the Fourth Republic was poor. The infrastructural facilities such as roads, schools, health sector were in shambles. The unemployment rate increased while crime became rampant. Another economic effect of the sleaze on the wider society in NNPC during the Fourth Republic is the chasm in income inequality. The Fourth Republic will go down in the history of the country as the most corrupt regime in the annals of the nation's history in the sense that no regime ever made so much money as was made under Obasanjo administration. It got to a point that the price of one barrel of crude oil was fetching $\$ 70$ and Nigeria at the time produced 3,150,000 (three million, one hundred and fifty thousand) barrels per day. Within the period, the Federal Government made more than $\$ 200,000,000$ (two hundred million U.S. dollars) everyday, including Sunday. ${ }^{56}$ Nonetheless, the sleaze in the NNPC in the Fourth Republic pauperize the Nigerian people to the benefit of a few within the circle of Obasanjo's cronies.

To conclude the paper, we offer some caveats to NNPC and the Nigerian government. What if the oil so depended on as the major source of foreign exchange and revenue got exhausted or that the U.S. and other 
Western countries find an alternative for oil? President Barack Obama during his campaign made the urgent search for alternative source of energy a key issue. ${ }^{57}$ What if this becomes possible? Then, Nigeria oil industry would become insignificant as foreign exchange. Therefore, the Nigerian government should regard oil and other natural resources as grants from God to build a sustainable future for Nigeria and her citizens. It is equally suggested that Nigeria should borrow a leaf from Norway.

Norway is one of the world's leading oil producing countries. It has vast oil and gas resources buried in Sandstone layers at the bottom of the North Sea. ${ }^{58}$ The country does not allow any abuse of the environment. In the management of its resources, it makes sure all is well directed to make room for the most ordinary citizens to feel the impact of the presence of oil and gas. It refineries are well run and efficient thus making no room for importation of fuel as it is done in Nigeria. Norway, unlike Nigeria, has not allowed the presence of vast oil and gas resources to neglect/abandon other sector especially agriculture. In its present undisclosed earnings, from the oil and gas, Norway keeps a special account which is being saved for the sake of posterity. ${ }^{59}$ The country's huge earnings from oil and gas are being invested in stocks and in setting up pension fund for workers. The country's earnings from oil and gas are reserved for the coming generations. They are invested in over 7,000 companies around the world. ${ }^{60}$ Nigeria via NNPC has a lot to learn from the management of oil and gas as well as other natural resources in Norway if only corruption would become a thing of the past.

\section{References}

[1]. http://www.nnpcgroup.com/NNPCBusinessInformation/OilGasinNigeria/IndustryHistory.aspx

[2]. Toyin Falola \& Matthew M. Heaton, A History of Nigeria, (New York: Cambridge University Press, 2008), p.154

[3]. Nwokeji G. Ugo, The NNPC \& the Developments of the Nigerian Oil \& Gas Industry: History, Strategies \& Current Discoveries, (U.S.A.: The James A. Baker III Institute for Public Policy: 2007), p.15

[4]. Chris Ajaero, A Chamber of Scandals, Newswatch, July 14, 2008, p.14

[5]. Maureen Chigbo, Gaius-Obaseki Vs the Oil Mafia, Newswatch, Novenber 3, 2008, p.28

[6]. Chris Ajaero, A Chamber of Scandal, ... pp.14-21

[7]. Cite Source

[8]. Nwokeji G. Ugo, The NNPC \& the Developments ... p.1

[9]. Ibid., p.12

[10]. Ibid.

[11]. Yinka Omorogbe, Oil and Gas Law in Nigeria, (Lagos: Malthouse Press Limited, 2001), p.20

[12]. Nwokeji G. Ugo, The NNPC and the Developments ... p.13

[13]. Pearson R. Scott, Petroleun and Nigerian Economy, (Stanford: University Press, 1970), pp.153-156

[14]. Zalik Anna, 'The Niger Delta: Petro Violence' and 'Partnership Development' Review of African Political Economy, 2004, pp.407408

[15]. Augustine A. Ikein, The Impact of Oil on a Developing Country: The Case of Nigeria, (New York: Praeger, 1990), pp.5-6

[16]. Nwokeji G. Ugo, The NNPC and the Developments ... p.14

[17]. http://www.nnpcgroup.com/NNPCBusinessInformation/OilGasinNigeria/IndustryHistory.aspx

[18]. Nwokeji G. Ugo, The NNPC and the Developments ... p.25

[19]. Terisa Turner, 'Commercial Capitalism and the 1975 Coup' in Soldiers and Oil: The Political Transformation of Nigeria, ed. Keith Panther-Brick, (London: Frank Class, 1978), pp.185-186

[20]. Federal Republic of Nigeria, Report of the Panel on Nigeria Crude Oil Production and Marketing Policies, Lagos, unpublished, March 1976.

[21]. Nwokeji G. Ugo, The NNPC and the Developments ... p.46-47

[22]. http://www.nnpcgroup.com/NNPCBusinessInformation/OilGasinNigeria/IndustryHistory.aspx

[23]. Nwokeji G. Ugo, The NNPC and the Developments ... p.46-47

[24]. Nenpominy Sarah Adelabu, The Political Economy of Oil Deregulation in Nigeria's Fourth Republic: Prospects and Challenges, Journal of Emerging Trends in Educational Research and Policy Studies, 3(3), 2012, p.183

[25]. http://www.en.wikipedia/wiki/Template:Cabinet_of_President_Obasanjo_1999 - 2003; Nkwokeji, The NNPC and the Developments ... pp.79-80; Mathias Oko in an interview with Gani Fawehinmi, SAN, Lagos Lawyer Human Rights Activist, entitled Obasanjo is the Most Corrupt Government Ever, Newswatch, October 20, 2003, p.45

[26]. Chris Ajaero, A chamber of Scandal, Newswatch, July 14 2008, p.14

[27]. Chidi Nnadi, FG Increases Petrol Price to 75 per litre, Daily Sun, Tuesday, May 29, 2007, p.6; Yakubu Lawal et al, Fuel Now N75 per litre, The Guardian, Monday, May 28, 2007, p.1

[28]. Mathias Oko, Obasanjo is the Most Corrupt Government ... p.45

[29]. Ibid., p.45

[30]. Desmond Utomwen, A Legacy of Waste, The News, June 4, 2007, p. 75

[31]. Yet to be sourced

[32]. Chris Ajaero, A Chamber of Scandals ... p.15

[33]. Ibid.

[34]. Bob Majirioghene, Nigeria's Rusty Refineries, TELL, November 17, 2008, p.25

[35]. Chris Ajaero, A Chamber of Scandals ... p.20

[36]. Ibid.

[37]. Semiu Salami, The Deal Gone Sour, Newswatch, August 6, 2007, p.20

[38]. Ibid.

[39]. Fola Adekeye, Thirty Most Corrupt Public Institutions in Nigeria, Newswatch, December 22, 2003, p.30

[40]. Chris Ajaero, A Chamber of Scandals ... p.21

[41]. Ibid.

[42]. Fola Adekeye, Thirty Most Corrupt Public Institution ... p.31

[43]. Chris Ajaero, A Chamber of Scandals ... p. 18

[44]. Ibid., p.19 
[45]. Demola Abimboye, House of Scandal, Newswatch, January 28, 2008, p. 28

[46]. Sam Adzegeh, Nigeria's Oil Smuggling Rings, Newswatch, October 13, 2003, p.33

[47]. Ibid., 34

[48]. Mikali Mumuni, Scandal on the High Sea, Newswatch, December 3, 2007, p48

[49]. Ibid., 47

[50]. Ibid., 48

[51]. Gani Fawehimi, Obasanjo is the Most Corrupt Nigerian, The News, June 4, 2007, pp.28-30

[52]. Ibid.

[53]. Ibid.

[54]. Mikali Mumuni, The Confessions of the Bribe Giver, Newswatch, December 17, 2007, pp.14-15

[55]. Ibid., p.16

[56]. Gani Fawehinmi, Obasanjo is the Most Corrupt ... p.29

[57]. Chukwuma Soludo, Who Will Reform Politics in Nigeria, a lecture delivered on the occasion of the Faculty of Social Sciences Home Coming marking the $50^{\text {th }}$ Aniversary of Nigeria Independence at the Princess Alexander Auditorium, University of Nigeria, Nsukka, June 3, 2010, p.3

[58]. Olayinka Oyegbile, How Norway Manages its Oil, Gas Fund, TELL, November 17, 2008, p.28

[59]. Ibid., 29

[60]. IBID. 